\title{
PENGARUH PEMBINAAN KEPALA SEKOLAH DAN KOMPENSASI TERHADAP KINERJA GURU NON PNS PADA SMP SWASTA DI SEKTOR I KABUPATEN INDRAMAYU
}

\author{
Eti Rahmawati \\ Universitas Wiralodra, Jln.Ir.H. Juanda Km 3 Indramayu Jawa Barat Indonesia, \\ etirahmawati3@gmail.com
}

Received November 27, 2018, reviewed Januari 30, 2019, published Maret 30, 2019

Citation: Rahmawati, E. (2019). Pengaruh Pembinaan Kepala Sekolah dan Kompensasi terhadap Kinerja Guru Non PNS pada SMP Swasta di Sektor I Kabupaten Indramayu. Edum Journal, Vol 2, No 1, Hal 2843, Maret 2019.

DOI:

\begin{abstract}
ABSTRAK
Rumusan masalah yang diangkat dalam penelitian ini adalah: Apakah ada pengaruh pembinaan kepala sekolah dan kompensasi terhadap kinerja guru non PNS pada SMP Swasta di Sektor I Kabupaten Indramayu. Tujuan dari penelitian ini adalah untuk menganalisis pengaruh pembinaan kepala sekolah terhadap kinerja guru dan kompensasi terhadap kinerja guru, dan pengaruh pembinaan kepala sekolah dan kompensasi secara simultan terhadap kinerja guru non PNS pada SMP Swasta di Sektor I Kabupaten Indramayu. Metode yang digunakan adalah metode deskriptif dengan pendekatan kuantitatif yang menggunakan analisis regresi sederhana dan berganda. Hasil dari penelitian ini adalah terdapat pengaruh yang positif dan signifikan secara parsial antara masing-masing variable independen yaitu pembinaan kepala sekolah dan kompensasi terhadap variable terikat yaitu kinerja guru, serta terdapat pengaruh yang positif dan signifikan Antara variable pembinaan kepala sekolah dan kompensasi secara simultan terhadap kinerja guru non PNS pada SMP Swasta di Sektor I Kabupaten Indramayu. Penelitian ini merupakan jenis korelasi karena untuk mengetahui hubungan variable pembinaan kepala sekolah $\left(\mathrm{X}_{1}\right)$, kompensasi $\left(\mathrm{X}_{2}\right)$ dan kinerja guru $(\mathrm{Y})$. Sedangkan pengumpulan data menggunakan angket dan dianalisis menggunakan regresi tunggal dan regresi ganda. Hasil pengujian hipotesisdiperoleh nilai $\mathrm{R}$ square sebesar 0,162 menunjukkan bahwa ada pengaruh secara positif dan signifikan pembinaan kepala sekolah dan kompensasi secara simultan terhadap kinerja guru sebesar 16,2\%, selebihnya dari faktor lain diluar kedua variable tersebut. Kepala sekolah dapat mempertahankan dan meningkatkan pembinannya terhadap guru dengan tetap melakukan secara rutin, kepala sekolah juga dapat menambah kegiatan pembinaan guru melalui kegiatan karyawisata, mengikuti seminar atau diklat kepala sekolah dan berusaha menjadi teladan bagi guru di sekolah.
\end{abstract}

Kata kunci: pembinaan, kompensasi, kinerja guru

\begin{abstract}
The formulation of the issues raised in this research is: Is there any influence of headmaster and compensation on the performance of non-civil servant teachers in private junior high school in Sector I of Indramayu Regency. The purpose of this research is to analyze the influence of principal guidance on teacher performance and compensation on teacher performance, and the influence of principal guidance and compensation simultaneously on the performance of non-civil servant teachers in private sector SMP in Sector I Kabupaten Indramayu. The method used is descriptive method with a quantitative approach that uses simple and multiple regression analysis. The result of this research is there is positive and significant influence partially between each independent variable that is principal guidance and compensation to dependent variable that is teacher performance, and there are positive and significant influence between principal coaching variable and compensation
\end{abstract}


simultaneously to performance non civil servant teachers at private junior high schools in Sector I Kabupaten Indramayu. This research is kind of correlation because to know the relation of principal guidance variable $\left(\mathrm{X}_{1}\right)$, compensation $\left(\mathrm{X}_{2}\right)$ and teacher performance $(\mathrm{Y})$. While the data collection using questionnaires and analyzed using single regression and multiple regression. Hypothesis testing result obtained by $\mathrm{R}$ square value equal to 0,162 indicate that there is influence positively and significant coaching principal and compensation simultaneously to teacher performance equal to $16,2 \%$, the rest from other factor outside of both variable. The principal can maintain and improve the teacher's reproduction by continuing to conduct regularly, the principal can also increase teacher training activities through field trips, attend seminars or headmaster training and try to be role models for teachers in schools.

Keywords: Guidance, compensation and teacher performance

\section{PENDAHULUAN}

Berhasil tidaknya suatu pendidikan sangatlah berpengaruh pada kinerja atau kemampuan profesional yang dimiliki oleh guru dalam melaksanakan pembelajaran (Dewi, dkk, 2018). Guru yang profesional akan tercermin dalam melaksanakan tugasnya sebagai pendidik yang ditandai dengan kemampuannya dalam mengelola pembelajaran (M. Shabir U., 2015). Guru juga memiliki tanggung jawab sosial yang dapat diwujudkan melalui kompetensi guru dalam memahami dirinya sebagai bagian yang tak terpisahkan dari lingkungan sosial serta memiliki kemampuan dalam berinteraksi dengan peserta didik, sebagaimana diungkapkan Mulyasa (2013:5), bahwa :

Sebagai pendidik dituntut untuk memiliki kinerja yang baik dalam pembelajaran agar tujuan pendidikan tercapai (Ahmad, 2017). Kinerja guru adalah wujud perilaku atau hasil kerja guru dalam melaksanakan pembelajaran mulai dari merencanakan pembelajaran, melaksanakan pembelajaran, mengevaluasi pembelajaran serta menilai hasil belajar peserta didik (Ismail, 2010). Guru yang memiliki kinerja atau kemampuan profesional yang baik diharapkan dapat memberikan hasil yang baik terhadap proses pembelajaran yang sesuai dengan tujuan pembelajaran. Kinerja guru yang bagus juga akan mempengaruhi prestasi peserta didik (Helmi, 2017).

Namun pada kenyataan dilapangan, kualitas kinerja di Indonesia masih sangat rendah, hal ini terlihat pada fakta di harian Kompas, 3 Agustus 2013 (Wulantika, 2013) bahwa rendahnya kualitas guru ini dapat dilihat dari rata-rata hasil Uji Kompetensi Guru 2012, yaitu 44,5 (Zubaidah, 2012), sedangkan nilai Uji Kompetensi Awal guru SMP 45,15 (Napitupulu, 2012). Hasil ini sangat jauh dari harapan pemerintah, yaitu 70.

Rendahnya kinerja guru SMP di Sektor I Kabupaten Indramayu juga terlihat dari dari hasil uji kompetensi guru (UKG) 
yang dilakukan pada tahun 2015 dengan yang diujikan memperoleh rata-rata 59,46\%. memperoleh hasil yang kurang memuaskan Hal ini bisa terlihat pada tabel berikut ini: karena hasil UKG dari 10 mata pelajaran

Tabel 1

Nilai Uji Kompetensi Guru SMP Negeri di Sektor I Kabupaten Indramayu Tahun 2015

\begin{tabular}{clc}
\hline No & \multicolumn{1}{c}{ Mata pelajaran } & Rata-Rata \\
\hline 1 & Pendidikan Kewarganegaraan & 69.03 \\
2 & Ilmu Pengetahuan Sosial & 55,77 \\
3 & Ilmu Pengetahuan Alam & 53,95 \\
4 & Bahasa Indonesia & 58,46 \\
5 & Bahasa Ingris & 53,92 \\
6 & Matematika & 61,04 \\
7 & Pendidikan Jasmani dan kesehatan & 53,93 \\
8 & Teknik Informatika Komputer & 70,68 \\
9 & Seni Budaya & 68,39 \\
10 & Bahasa Indramayu & 49,40 \\
\hline & Rata-Rata & $\mathbf{5 9 , 4 6}$ \\
\hline
\end{tabular}

Sumber: Dinas Pendidikan Kabupaten Indramayu tahun 2015 Nasional (UN) Tahun ajaran 2014/2015,

Dari data diatas rendahnya kualitas terlihat masih terdapat nilai rendah dalam kinerja berpengaruh terhadap rendahnya beberapa mata pelajaran sehingga tidak prestasi siswa sekolah menengah pertama memenuhi target nilai minimal 7.50 yang (SMP) di Kabupaten Indramayu. Hal ini sudah ditetapkan. Hasil nilai Ujian Nasional terlihat dari hasil observasi awal yang tahun ajaran 2014/2015 terlihat dalam tabel dilakukan penulis terhadap nilai ujian berikut ini :

Tabel 2

Data Hasil Ujian Nasional (UN) SMP di Kabupaten Indramayu

\begin{tabular}{lccccc}
\hline Nilai Ujian & $\begin{array}{c}\text { Bahasa } \\
\text { Indonesia }\end{array}$ & Matematika & IPA & $\begin{array}{c}\text { Bahasa } \\
\text { Inggris }\end{array}$ & $\begin{array}{c}\text { Jumlah } \\
\text { nilai }\end{array}$ \\
\hline Rata-rata & 7,74 & 8,25 & 7,88 & 7,25 & 31,12 \\
Terendah & 4,21 & 3,25 & 4,25 & 4,05 & 15,76 \\
Tertinggi & 9,60 & 9,98 & 9,50 & 9,40 & 38,48 \\
Standar & 0,58 & 0,62 & 0,57 & 0,52 & 2,29 \\
Deviasi & & & & & \\
\hline
\end{tabular}

Sumber: Dinas Pendidikan Kabupaten Indramayu

Rendahnya kinerja guru yang terjadi \& Suherman, 2010:29) menjelaskan lima dilapangan ditimbulkan oleh banyak faktor, penyebab rendahnya profesionalisme guru sebagaimana diungkapkan Akadum (Saondi yaitu: (1) Masih banyak guru tidak 
menekuni profesinya secara total. (2) Rentan dan rendahnya kepatuhan guru terhadap norma dan etika profesi keguruan. (3) Pengakuan terhadap ilmu pendidikan dan keguruan masih setengah hati dari pengambilan kebijakan dan pihak-pihak terlibat. Hal initerbukti masih belum mantapnya lembaga pencetak tenaga keguruan dan kependidikan. (4) Masih belum smoothnya perbedaan pendapat tentang proporsi materi ajar yang diberikan kepada calon guru. (5) Masih belum berfungsinya PGRI sebagai organisasi profesi yang berupaya secara maksimal meningkatkanprofesionalisme anggotanya.

Berdasarkan hasil observasi dan wawancara pendahuluan dengan kepala sekolah dan guru sekolah swasta di SMP Perintis Pasekan, SMP Endang Dharma Indramayu, SMP Fatahilah Lohbener, SMP PGRI Sindang, dan SMP NU Karang Anyar pada tanggal 17 Oktober sampai 20 Oktober 2016, terdapat permasalahan terkait dengan pelaksanaan tugas dan tanggung jawab guru yang tidak sesuai dengan yang diharapkan dalam indikator kinerja guru. Hal ini terbukti dengan adanya guru yang sering meninggalkan sekolah di saat ada jam mengajar dikarenakan harus mengajar di sekolah lain demi mengejar penghasilan lebih untuk memenuhi kebutuhan hidupnya.

Masalah lain yang dihadapi guru terkait dengan kemampuan guru dalam pembelajaran adalah cara mengajar guru masih bersifat konvensional dengan mempergunakan satu atau dua metode. Masalah berikutnya yang didapati peneliti masih banyak guru yang mengajar dengan sistem gaya bank. Sistem ini memiliki ciri dan kebiasaan bahwa guru mengetahui segalanya sementara siswa tidak tahu apaapa, guru bercerita peserta didik patuh mendengarkan, guru memilih bahan ajar dan isi pelajaran murid tanpa menyesuaikan diri dengan materi pelajaran, dan masalah guru selanjutnya adalah masih kesulitan penyusunan rencana pelaksanaan pembelajaran, guru belum menyusun RPP sesuai dengan kurikulum/silabus dan sesuai dengan karakteristik peserta didik.

Berdasarkan paparan di atas, perlu adanya upaya peningkatan kemampuan dan kinerja guru yang dapat dilakukan oleh kepala sekolah dengan cara pembinaan profesional. Peran kepala sekolah sebagai pemimipin pendidikan sangat besar mempengaruhi kinerja guru dalam meningkatkan mutu pendidikan di sekolah. Kepala sekolah sebagai pemimpin harus memberikan perhatian yang sungguhsungguh terhadap usaha-usaha mendayagunakan, memajukan, dan meningkatkan kemampuan profesional guru secara terus menerus melalui pembinaan. Kepala sekolah sebagai pembina diharapkan dapat berkunjung ke kelas secara berkala 
untuk membina dan mengamati kegiatan guru mulai dari perencanaan pembelajaran, pelaksanaan pembelajaran, dan evaluasi pembelajaran.

Pelaksanaan pembinaan oleh kepala sekolah yang bersifat akademik atau teknik edukatif harus mendapatkan perhatian yang lebih besar dari kepala sekolah, karena pembinaan tersebut merupakan pembinaan yang berhubungan langsung dengan pengajaran.

Berdasarkan hasil wawancara dengan guru bidang studi kelas VII, VIII dan IX sekolah swasta di SMP Perintis Pasekan, SMP Endang Dharma, SMP PGRI Sindang dan SMP NU Karang Anyar pada tanggal 17 Oktober sampai 20 Oktober 2016 peneliti mendapati informasi bahwa kegiatan pembinaan profesional guru oleh kepala sekolah dilaksanakan secara internal dan eksternal.

\section{METODELOGI PENELITIAN}

Metode penelitian yang digunakan yakni metode deskriptif korelasional dengan menggunakan pendekatan kuantitatif dan desain ex post facto. Menurut Sugiyono (2014 :7), penelitian expost facto adalah penelitian yang bertujuan untuk menyelidiki peristiwa yang telah terjadi dan kemudian merunut kebelakang untuk mengetahui faktor-faktor yang menyebabkan terjadinya peristiwa tersebut.

Dalam penelitian ini variabel yang akan diukur terdiri dari dua variabel bebas dengan notasi $\left(\mathrm{X}_{1}\right)$ dan $\left(\mathrm{X}_{2}\right)$, dan satu variabel terikat dengan notasi (Y). Adapun variabel-variabel tersebut adalah sebagai berikut:

a. Variabel bebas (independent variable) pertama dengan notasi $\left(\mathrm{X}_{1}\right)$ yaitu variabel yang memberikan pengaruh terhadap variabel terikat, variabel tersebut adalah pembinaan kepala sekolah yang meliputi:

Pengembangan intensif (Intensive development), (2) Pengembangan kooperatif (Cooperatif development), (3) Pengembangan diri sendiri (Self directed development)

b. Variabel bebas (independent variable) kedua dengan notasi $\left(\mathrm{X}_{2}\right)$ yaitu variabel yang memberikan pengaruh terhadap variabel terikat, variabel tersebut adalah kompensasi, yang meliputi : Kompensasi Finansial, (2) Kompensasi non finansial.

c. Variabel terikat (dependent variable) dengan notasi $(\mathrm{Y})$ yaitu variabel yang dipengaruhi atau menjadi akibat adanya variabel bebas (independent variable), variabel tersebut adalah kinerja guru yang meliputi: (1) Kualitas Kerja (Quality of work), 
Kecepatan/ketepatan Kerja (Proptness),

(3) Insiatif dalam kerja (Initiatif),

Kemampuan kerja Capability),

Komunikasi (Communication).

Populasi dalam penelitian ini merupakan seluruh guru non PNS pada pada SMP swasta yang tersebar di 21 SMP swasta dengan jumlah 308 guru di sektor 1 Kabupaten Indramayu. Sampel yang diambil yakni 75 orang.

Analsis data dalam penelitian ini merupakan upaya menyelidiki secara

HASIL

PENELITIAN

DAN

\section{PEMBAHASAN}

Berdasarkan hasil uji normalitas kolmogorov-smirnov terlihat dari nilai Asymp. Sig. (2-tailed) sebesar 0,200, jadi probabilitas $>0,05$, maka data penelitian berdistribusi normal. Disamping dengan menggunakan uji kolmogorov-mirnov, uji mendalam terhadap data yang berhasil diperoleh peneliti selama penelitian berlangsung, sehingga akan diketahui makna dan keadaan yang sebenarnya dari apa yang diteliti. Analisis data ini dilakukan untuk menjadikan data bermakna atau berarti melalui langkah-langkah yang sistematis, sehingga akhirnya peneliti dapat menggunakan data-data itu untuk membuat kesimpulan hasil penelitian.

normalitas ini juga didukung dari hasil gambar grafik normal probability plot. Apabila variabel berdistribusi normal maka penyebaran plot akan berada disekitar dan disepanjang garis 45 derajat.

Hasil dari uji linieritas dengan menggunakan program SPSS 24 adalah sebagai berikut:

Tabel 3

Hasil Uji Linieritas Variabel $X_{1}$ terhadap Y ANOVA Table

\begin{tabular}{|c|c|c|c|c|c|c|c|}
\hline & & & $\begin{array}{l}\text { Sum of } \\
\text { Squares }\end{array}$ & df & $\begin{array}{l}\text { Mean } \\
\text { Square }\end{array}$ & $\mathrm{F}$ & Sig. \\
\hline \multirow{5}{*}{$\begin{array}{l}\text { Kinerja_Guru } * \\
\text { Pembinaan_Kepa } \\
\text { la_Sekolah }\end{array}$} & \multirow[t]{3}{*}{ Between Groups } & (Combined) & 3256.084 & 50 & 65.122 & 1.233 & .000 \\
\hline & & Linearity & 551.839 & 1 & 551.839 & 10.448 & .000 \\
\hline & & $\begin{array}{l}\text { Deviation from } \\
\text { Linearity }\end{array}$ & 2704.246 & 49 & 55.189 & 1.045 & .226 \\
\hline & \multicolumn{2}{|l|}{ Within Groups } & 1267.638 & 35 & 52.818 & & \\
\hline & \multicolumn{2}{|l|}{ Total } & 4523.722 & 74 & & & \\
\hline
\end{tabular}

Sumber: Hasil output Linieritas Test SPSS 24

Tabel 4

Hasil Uji Linieritas Variabel $X_{2}$ terhadap Y ANOVA Table

\begin{tabular}{|c|c|c|c|c|c|c|c|}
\hline & & & $\begin{array}{l}\text { Sum of } \\
\text { Squares }\end{array}$ & $\mathrm{df}$ & $\begin{array}{l}\text { Mean } \\
\text { Square }\end{array}$ & $\mathrm{F}$ & Sig. \\
\hline \multirow{2}{*}{$\begin{array}{l}\text { Kinerja_Guru } * \\
\text { Kompensasi }\end{array}$} & \multirow{2}{*}{ Between Groups } & (Combined) & 3422.881 & 51 & 67.115 & 1.402 & .000 \\
\hline & & Linearity & 359.568 & 1 & $\begin{array}{r}359.56 \\
8\end{array}$ & 7.512 & .000 \\
\hline
\end{tabular}




\begin{tabular}{lll|l|l|l|r|r}
\hline & $\begin{array}{l}\text { Deviation from } \\
\text { Linearity }\end{array}$ & 3063.312 & 50 & 61.266 & 1.280 & .226 \\
\cline { 2 - 7 } & & 1100.842 & 38 & 47.863 & & \\
\hline Within Groups & & 4523.722 & 74 & & & \\
\hline Total & &
\end{tabular}

Sumber: Hasil output Linieritas Test SPSS 24

Berdasarkan hasil output uji linieritas pada pada bab sebelumnya, maka langkah tabel 4.25 dan 4.26 terlihat bahwa nilai selanjutnya adalah uji hipotesis.

signifikansi (defiation from linierity) lebih dari 0,05. Dapat disimpulkan bahwa variabel pembinaan kepala sekolah dan variabel kompensasi terhadap variabel kinerja guru mempunyai hubungan yang linier.

\section{Pengujian Hipotesis Penelitian}

Setelah diketahui bahwa data berdistribusi normal dan berpola linier sebagaimana terlihat pada hasil pengujian

\section{Pengaruh Pembinaan Kepala Sekolah} $\left(\mathbf{X}_{1}\right)$ Terhadap Kinerja Guru (Y)

Untuk menguji hipotesis pengaruh pembinaan kepala sekolah $\left(X_{1}\right)$ terhadap kinerja guru (Y) dalam penelitian ini dilakukan dengan uji pearson correlation dan uji regresi linear dengan menggunakan software SPSS versi 24 diperoleh hasil seperti tabel dibawah ini :

\section{Tabel 5}

Hasil Uji Korelasi Variabel $X_{1}$ dan $Y$ Correlations

\begin{tabular}{llr|r}
\hline & & $\begin{array}{c}\text { Pembinaan_Kep } \\
\text { ala_Sekolah }\end{array}$ & Kinerja_guru \\
\hline Pembinaan_Kepala_Sekolah & Pearson Correlation & 1 & $.469^{* *}$ \\
\cline { 2 - 4 } & Sig. (2-tailed) & 75 & .008 \\
\cline { 2 - 4 } Kinerja_guru & $\mathrm{N}$ & $.469^{* *}$ & 75 \\
\hline & Pearson Correlation & .008 & 1 \\
\cline { 2 - 4 } & Sig. (2-tailed) & 75 & 75 \\
\cline { 2 - 5 } & $\mathrm{N}$ & & \\
\hline
\end{tabular}

**. Correlation is significant at the 0.01 level (2-tailed).

Berdasarkan hasil perhitungan tabel 4.15 diatas, besarnya hubungan pembinaan kepala sekolah $\left(\mathrm{X}_{1}\right)$ dengan kinerja guru $(\mathrm{Y})$ yang dihitung dengan pearson correlation adalah 0,469 . Hal ini menunjukan adanya hubungan yang positif antara pembinaan kepala sekolah dengan kinerja guru.

\section{Tabel 6}

\section{Koefisien Persamaan Regresi Variabel $X_{1}$ dan Y}

\begin{tabular}{|c|c|c|c|c|c|c|}
\hline \multirow{2}{*}{\multicolumn{2}{|c|}{ Model }} & \multicolumn{2}{|c|}{$\begin{array}{l}\text { Unstandardized } \\
\text { Coefficients }\end{array}$} & $\begin{array}{l}\text { Standardized } \\
\text { Coefficients }\end{array}$ & \multirow[b]{2}{*}{$\mathrm{t}$} & \multirow[b]{2}{*}{ Sig. } \\
\hline & & $\mathrm{B}$ & Std. Error & Beta & & \\
\hline 1 & (Constant) & 7.329 & 1.832 & & 4.001 & .000 \\
\hline & $\begin{array}{l}\text { Pembinaan_Kepala_Sekol } \\
\text { ah }\end{array}$ & .719 & .048 & .469 & 3.801 & .008 \\
\hline
\end{tabular}

a. Dependent Variable: Kinerja_guru 
Persamaan regresi dari hasil perhitungan diperoleh $\hat{y}=\mathrm{a}+\mathrm{bx}_{1}, \hat{y}=7,329+0,469 \mathrm{x}_{1}$. Konstanta sebesar 7,329 menyatakan bahwa jika tidak ada kenaikan nilai dari variabel pembinaan kepala sekolah $\left(\mathrm{X}_{1}\right)$ maka kinerja guru adalah 7,329. Koefisien regresi sebesar 0,719 menyatakan bahwa setiap perubahan satu skor atau nilai pembinaan kepala sekolah memberikan kenaikan skor sebesar 0,719. Kemudian pengujian signifikan dilakukan dengan membandingkan antara nilai probabilitas 0,05 dengan nilai probabilitas pada nilai Sig pada tebel 4.28. Nilai Sig sebesar 0,002, karena 0,002 $<0,05$ maka terdapat pengaruh pembinaan kepala

sekolah $\left(X_{1}\right)$ yang signifikan terhadap kinerja guru $(\mathrm{Y})$.

Berdasarkan pengujian hipotesis pertama dapat diketahui bahwa nilai Sig $(0,002<0,05)$ maka hasilnya Ho ditolak dan Ha diterima, artinya terdapat pengaruh positif dan signifikan pembinaan kepala sekolah terhadap kinerja guru kinerja guru non PNS SMP Swasta di sektor 1 Kabupaten Indramayu.

Untuk menyatakan besar kecilnya pengaruh variabel $\mathrm{X}_{1}$ terhadap $\mathrm{Y}$ dengan cara menghitung besarnya koefisien determinasi dan diolah dengan software SPSS versi 24 pada tabel 7 berikut :

Tabel 7 Koefisien Determinasi Variabel $X_{1}$ terhadap Y

Model Summary

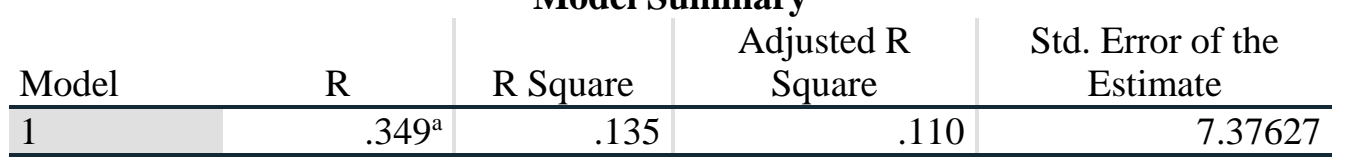

a. Predictors: (Constant), Pembinaan_Kepala_Sekolah

Dari tabel 4.29 diketahui bahwa R Square Untuk menguji hipotesis pengaruh 0,135 , berarti koefisien $=13,5 \%$, artinya kompensasi $\left(\mathrm{X}_{2}\right)$ terhadap kinerja guru $(\mathrm{Y})$ variabel $\mathrm{Y}$ dipengaruhi oleh variabel $\mathrm{X}_{1}$ dalam penelitian ini dilakukan dengan uji sebesar $13,5 \%$ dan sisanya sebasar $86,5 \%$ pearson correlation dan uji regresi linear dipengaruhi oleh variabel $\mathrm{X}_{2}$ dan variabel dengan menggunakan software SPSS versi lain yang tidak diteliti dalam penelitian ini. $\quad 24$ diperoleh hasil seperti tabel dibawah ini :

\section{Pengujian Hipotesis Kompensasi ( $\left.\mathbf{X}_{2}\right)$}

\section{Terhadap Kinerja Guru (Y)}

Tabel 8

Hasil Uji Korelasi Variabel $\mathbf{X}_{2}$ dan $\mathbf{Y}$

\section{Correlations}

Kompensasi Kinerja_guru 


\begin{tabular}{llrr}
\hline Kompensasi & Pearson Correlation & 1 & $.352^{* *}$ \\
\cline { 2 - 4 } & Sig. (2-tailed) & 75 & .015 \\
\cline { 2 - 4 } & $\mathrm{N}$ & $.352^{* *}$ & 75 \\
\hline Kinerja_guru & Pearson Correlation & .015 & 15 \\
\cline { 2 - 4 } & Sig. (2-tailed) & 75 & 75 \\
\cline { 2 - 4 } & $\mathrm{N}$ & & 75 \\
\hline
\end{tabular}

**. Correlation is significant at the 0.01 level (2-tailed).

Berdasarkan hasil perhitungan tabel 8 diatas, pearson correlation adalah 0,282 . Hal ini besarnya hubungan kompensasi $\left(\mathrm{X}_{2}\right)$ dengan menunjukan adanya hubungan yang positif kinerja guru (Y) yang dihitung dengan antara kompensasi dengan kinerja guru.

\section{Tabel 9}

\section{Koefisien Persamaan Regresi Variabel $X_{2}$ dan Y}

\section{Coefficients $^{\mathrm{a}}$}

\begin{tabular}{|c|c|c|c|c|c|c|}
\hline & \multirow[b]{2}{*}{ Model } & \multicolumn{2}{|c|}{$\begin{array}{c}\text { Unstandardized } \\
\text { Coefficients }\end{array}$} & \multirow{2}{*}{$\begin{array}{c}\text { Standardized } \\
\text { Coefficients } \\
\text { Beta }\end{array}$} & \multirow[b]{2}{*}{$\mathrm{t}$} & \multirow[b]{2}{*}{ Sig. } \\
\hline & & B & Std. Error & & & \\
\hline \multirow[t]{2}{*}{1} & (Constant) & 34.132 & 5.195 & & 6.955 & .000 \\
\hline & Kompensasi & .379 & .115 & .352 & 2.511 & .015 \\
\hline
\end{tabular}

a. Dependent Variable: Kinerja_guru

Persamaan regresi dari hasil perhitungan maka terdapat pengaruh kompensasi $\left(\mathrm{X}_{2}\right)$ diperoleh $\hat{y}=\mathrm{a}+\mathrm{bx}_{2}, \hat{y}=34,132+0,379 \mathrm{x}_{2} . \quad$ yang signifikan terhadap kinerja guru (Y).

Konstanta sebesar 34,132 menyatakan bahwa jika tidak ada kenaikan nilai dari variabel kompensasi $\left(\mathrm{X}_{2}\right)$ maka kinerja guru adalah 34,132. Koefisien regresi sebesar 0,352 menyatakan bahwa setiap perubahan satu skor atau nilai kompensasi memberikan kenaikan skor sebesar 0,379.

Kemudian pengujian signifikan dilakukan dengan membandingkan antara nilai probabilitas 0,05 dengan nilai probabilitas pada nilai Sig pada tebel 4.16. Nilai Sig sebesar 0,015, karena 0,015 <0,05
Berdasarkan penjelasan diatas, maka pengujian hipotesis kedua dalam penelitian ini dapat diketahui bahwa nilai Sig $(0,015<$ 0,05 ) maka hasilnya $\mathrm{Ho}$ ditolak dan $\mathrm{Ha}$ diterima, artinya terdapat pengaruh positif dan signifikan iklim organisasi terhadap kinerja guru non PNS SMP Swasta di sektor 1 Kabupaten Indramayu.

Untuk menyatakan besar kecilnya pengaruh variabel $\mathrm{X}_{2}$ terhadap $\mathrm{Y}$ dengan cara menghitung besarnya koefisien determinasi dan diolah dengan software SPSS versi 24 pada tabel 9 berikut: 


\section{Koefisien Determinasi Variabel $\mathrm{X}_{2}$ terhadap Y Model Summary}

\begin{tabular}{lr|r|r|r} 
Model & R Square & Adjusted R Square & Std. Error of the Estimate \\
\hline 1 & .119 & .067 & 7.55270 \\
\hline a. Predictors: (Constant), Kompensasi
\end{tabular}

Dari tabel 10 diketahui bahwa $\mathrm{R}$ Square 0,079 , berarti koefisien $=11,9 \%$, artinya variabel $\mathrm{Y}$ dipengaruhi oleh variabel $\mathrm{X}_{2}$ sebesar $11,9 \%$ dan sisanya sebasar $88,1 \%$ dipengaruhi oleh variabel $\mathrm{X}_{1}$ dan variabel lain yang tidak diteliti dalam penelitian ini.

Pengujian Hipotesis Pengaruh

Pembinaan Kepala Sekolah $\left(\mathbf{X}_{1}\right)$ \&

Kompensasi $\left(\mathrm{X}_{2}\right)$ Secara Bersama-sama

Terhadap Kinerja Guru (Y)
Untuk menguji hipotesis pengaruh pembinaan kepala sekolah $\left(\mathrm{X}_{1}\right)$ dan kompensasi $\left(\mathrm{X}_{2}\right)$ secara bersama-sama terhadap kinerja guru (Y) dalam penelitian ini dilakukan dengan uji regresi linear dan regresi ganda dengan menggunakan software SPSS versi 24 diperoleh hasil seperti tabel dibawah ini

\section{Tabel 11 Koefisien Persamaan Regresi Variabel $Y$ atas $\mathrm{X}_{1}$ dan $\mathrm{X}_{2}$}

\begin{tabular}{|c|c|c|c|c|c|c|}
\hline & \multirow[b]{2}{*}{ Model } & \multicolumn{2}{|c|}{$\begin{array}{l}\text { Unstandardized } \\
\text { Coefficients }\end{array}$} & \multirow{2}{*}{$\begin{array}{c}\text { Standardized } \\
\text { Coefficients } \\
\text { Beta }\end{array}$} & \multirow[b]{2}{*}{$\mathrm{t}$} & \multirow[b]{2}{*}{ Sig. } \\
\hline & & B & Std. Error & & & \\
\hline \multirow[t]{3}{*}{1} & (Constant) & 25.472 & 5.800 & & 3.981 & .000 \\
\hline & $\begin{array}{l}\text { Pembinaan_Kepala_Sekol } \\
\text { ah }\end{array}$ & 284 & 105 & 287 & $\begin{array}{l}3.4 \\
95\end{array}$ & .008 \\
\hline & Kompensasi & .230 & .118 & .186 & 2.514 & .014 \\
\hline
\end{tabular}

a. Dependent Variable: Kinerja_guru

kenaikan nilai dari variabel pembinaan kepala sekolah $\left(\mathrm{X}_{1}\right)$ dan kompensasi $\left(\mathrm{X}_{2}\right)$ maka kinerja guru (Y) adalah 25.472. Koefisien regresi sebesar 0,284 dan 0,230

Pada tabel 11 menunjukkan persamaan menyatakan bahwa setiap perubahan satu regresi dari hasil perhitungan olah data skor atau nilai pembinaan kepala sekolah dengan software SPSS versi 24 yaitu: $\hat{y}=$ dan kompensasi akan memberikan kenaikan $25,472+0,284 \mathrm{X}_{1}+0,230 \mathrm{X}_{2}$. Konstanta skor 0,284 dan 0,230 unit pada kinerja guru. sebesar 25,472 menyatakan bahwa jika tidak Persamaan tersebut akan diuji secara 
statistik apakah signifikan atau tidak seperti

pada tabel 4.34 berikut ini:

Tabel 12 Hasil Uji Signifikasi Regesi Variabel $Y$ atas $\mathrm{X}_{1}$ dan $\mathrm{X}_{2}$

\begin{tabular}{|c|c|c|c|c|c|c|}
\hline \multicolumn{7}{|c|}{ ANOVA $^{a}$} \\
\hline & & Sum of Squares & df & Mean Square & $\mathrm{F}$ & Sig. \\
\hline \multirow[t]{3}{*}{1} & Regression & 689.989 & 2 & 344.994 & 5.379 & $.003^{\mathrm{b}}$ \\
\hline & Residual & 3833.733 & 72 & 53.246 & & \\
\hline & Total & 4523.722 & 74 & & & \\
\hline
\end{tabular}

a. Dependent Variable: Kinerja_Guru

b. Predictors: (Constant), Kompensasi, Pembinaan_Kepala_Sekolah

Pengujian signifikasi untuk kompensasi $\left(\mathrm{X}_{2}\right)$ secara bersama - sama perhitungan regresi digunakan uji $\mathrm{F}$ pada terhadap kinerja guru (Y) non PNS SMP tabel 12 menunjukan bahwa $F_{\text {hitung }}$ sebesar Swasta di sektor 1 Kabupaten Indramayu.

5,379 dengan taraf signifikasi 0,003 kurang Untuk mengetahui adanya pengaruh dari taraf nyata $0,05(\alpha=5 \%)$ dan jika positif dan berapa besar pengaruh dibandingkan dengan $F_{\text {tabel }}$ dengan pembinaan kepala sekolah $\left(\mathrm{X}_{1}\right)$ dan kesalahan uji $5 \%$ derajat bebas 1 (dfi) sama kompensasi $\left(\mathrm{X}_{2}\right)$ secara bersama - sama dengan 2 dan derajat bebas 2 (df2) sama terhadap kinerja guru (Y) non PNS SMP dengan 73 sebesar 3,120, maka $F_{\text {hitung }}>$ Swasta di sektor 1 Kabupaten $F_{\text {tabel }}$ berarti persamaan $\hat{y}=25,472+$ Indramayu.dilakukan uji korelasi gand $0,284 \mathrm{X}_{1}+0,230 \mathrm{X}_{2}$ signifikan. Artinya terdapat pengaruh yang signifikan antara dengan hasil seperti pada tabel 4.35 berikut ini :

pembinaan kepala sekolah $\left(\mathrm{X}_{1}\right)$ dan

Tabel 13

Perhitungan Uji Regresi Ganda

Model Summary

\begin{tabular}{lr|r|r|r} 
Model & $\mathrm{R}$ & R Square & Adjusted R Square & Std. Error of the Estimate \\
\hline 1 & $.391^{\mathrm{a}}$ & .162 & .129 & 7.29701 \\
\hline
\end{tabular}


a. Predictors: (Constant), Kompensasi, Pembinaan_Kepala_Sekolah

b. Dependent Variable: Kinerja Guru

Berdasarkan hasil perhitungan program SPSS di atas, besarnya hubungan korelasi ganda antara variabel pembinaan kepala sekolah $\left(\mathrm{X}_{1}\right)$ dan kompensasi $\left(\mathrm{X}_{2}\right)$ secara bersama - sama terhadap kinerja guru (Y) adalah 0,391. Hal ini menunjukan adanya pengaruh yang positif antara pembinaan kepala sekolah $\left(\mathrm{X}_{1}\right)$ dan kompensasi $\left(\mathrm{X}_{2}\right)$ secara bersama - sama terhadap kinerja guru (Y) .

Berdasarkan penjelasan diatas, maka pengujian hipotesis ketiga dalam penelitian ini, hasil akhirnya $\mathrm{Ho}$ ditolak dan $\mathrm{Ha}$ diterima, artinya terdapat pengaruh positif dan signifikan pembinaan kepala dan kompensasi secara simultan terhadap kinerja guru non PNS SMP Swasta di sektor 1 Kabupaten Indramayu.. Sedangkan untuk menyatakan besar kecilnya pengaruh variabel pembinaan kepala sekolah $\left(\mathrm{X}_{1}\right)$ dan kompensasi $\left(\mathrm{X}_{2}\right)$ secara simultan terhadap kinerja guru (Y) dapat diketahui dari tabel diatas $\mathrm{R}^{2}$ sebesar 0,162. Ini memberikan arti bahwa pengaruh pembinaan kepala sekolah $\left(\mathrm{X}_{1}\right)$ dan kompensasi $\left(\mathrm{X}_{2}\right)$ secara simultan terhadap kinerja guru (Y) sebesar 16,2\% sedangkan sisanya $83,8 \%$ ditentukan oleh faktor yang lain.

\section{Pembahasan}

\section{Pengaruh Pembinaan Kepala Sekolah terhadap Kinerja Guru}

Berdasarkan hasil uji hipotesis yang telah dilakukan bahwasannya kepemimpinan transformasional kepala sekolah mempunyai nilai yang signifikan terhadap kinerja guru. Sehingga $\mathrm{H}_{\mathrm{a}}$ yang menyatakan bahwa ada pengaruh pembinaan kepala sekolah terhadap kinerja guru diterima. Sedangkan hasil analisis deskriptif presentase penelitian menunjukkan bahwa pembinaan kepala sekolah SMP swasta di sektor 1 Kabupaten Indramayu sebesar 13,5\%. Hal ini memberikan gambaran bahwa pembinaan yang telah dijalankan, terlaksana dengan baik. Bahwa pembinaan kepala sekolah telah memberikan efek yang positif terhadap guru dalam bekerja.

Pembinaan kepala sekolah sangat penting dalam meningkatkan kinerja guru. Hal ini sesuai dengan pendapat Dajadisastra yang dikutip oleh Imron (2015:12) bahwa tujuan dari adanya pembinaan guru Antara lain 1) memperbaiki tujuan khusus mengajar guru dan belajar siswa, 2) memperbaiki materi (bahan) dan kegiatan belajar mengajar, 3) memperbaiki metode yaitu cara mengorganisasikan kegiatan belajar mengajar, 4) memperbaiki penilaian atas 
media, 5) memperbaiki penilaian proses belajar mengajar, 6) memperbaiki bimbingan siswa atas kesulitan belajar, dan 7) memperbaiki sikap guru atas tugasnya. Dengan adanya kegiatan pembinaan yang dilakukan oleh kepala sekolah secara intens maka dapat memperbaiki efektifitas kinerja guru dalam mencapai hasil yang optimal. Dengan demikian proses belajar mengajar berjalan dengan baik dan guru dapat bekerja professional dalam melaksanakan tugasnya.

Pembinaan yang dilakukan dengan baik oleh kepala sekolah, guru dapat menumbuhkemabngkan kemampuan yang dimiliki seperti pertumbuhn keilmuan, wawasan berpikir, sikap terhadap pekerjaan dan keterampilan dalam melaksanakan tugasnya sehari-hari. Dengan demikian kinerja guru akan meningkat, sebagai upaya untuk mendukung tercapainya tujuan pendidikan, pembinaan kepala sekolah terhadap kinerja guru non PNS SMP Swasta di sektor 1 Kabupaten Indramayu memberikan dampak yang baik dalam pelaksanaan kerja yang benar secara teratur.

Pengaruh kompensasi terhadap Kinerja Guru

Program kompensasi penting bagi organisasi karena mencerminkan upaya organisasi untuk mempertahankan sumber daya manusia sebagai komponen utama, dan merupakan komponen biaya yang paling penting. Disamping pertimbangan tersebut, kompensasi juga merupakan salah satu aspek yang berarti bagi pegawai, karena individu/pegawai besarnya kompensasi mencerminkan ukuran nilai karya mereka diantara pegawai itu sendiri, keluarga dan masyarakat. Bila kompensasi diberikan secara benar, pegawai akan termotivasi dan lebih terpusatkan untuk mencapai sasaransasaran organisasi. Suatu kompensasi harus memiliki dasar yang logis, kuat dan tidak mudah goyah serta adil.

Berdasarkan hasil uji hipotesis yang telah dilakukan bahwasannya kompensasi mempunyai nilai yang signifikan terhadap kinerja guru non PNS. Sehingga $\mathrm{H}_{2}$ yang menyatakan bahwa ada pengaruh kompensasi terhadap kinerja guru diterima. Sedangkan hasil analisis deskriptif presentase penelitian menunjukkan bahwa kompensasi yang diberikan kepada guru non PNS SMP Swasta di sekor 1 Kabupaten Indramayu sebesar 11,9\%. Hal ini menggambarkan bahwa secara keseluruhan kompensasi pada SMP Swasta di sektor 1 Kabupaten Indramayu sudah diberikan sesuai dengan taraf kemampuan rumah tangga sekolah.

\section{Pengaruh Pembinaan Kepala Sekolah} dan Kompensasi terhadap Kinerja Guru.

Wibowo dalam Dekawati (2011:73) mengemukakan bahwa kinerja adalah implementasi dari rencana yang telah disusun. Implementasi kinerja dilakukan 
oleh sumber daya manusia yang memiliki kemampuan, kompetensi, motivasi dan kepentingan. Organisasi memiliki andil dalam implementasi kinerja, yaitu bagaimana organisasi menghargai dan memperlakukan sumber daya manusianya akan mempengaruhi sikap dan perilakunya dalam menjalankan kinerja.

Diantara hal-hal yang dapat memotivasi kinerja guru adalah adanya pembinaan, penghargaan, pengakuan dan kompensasi yang layak sesuai dengan kinerjanya. Adanya pembinaan yang dilakukan oleh kepala sekolah juga seringkali dapat memotivasi guru agar dapat meningkatkan kinerjanya. Berdasarkan paparan diatas, maka dapat disimpulkan bahwa guru merupakan kunci keberhasilan proses pendidikan. Sehingga kinerja guru dan hal-hal yang dapat mempengaruhinya, diantaranya variable kompensasi dan kegiatan pembinaan kepala sekolah merupakan kajian yang penting dalam ilmu manajemen pendidikan.

Berdasarkan hasil uji hipotesis yang telah dilakukan bahwasannya pembinaan kepala sekolah dan kompensasi secara simultan berpengaruh terhadap kinerja guru non PNS SMP Swasta di Sektor 1 Kabupaten Indramayu. Besarnya pengaruh pembinaan kepala sekolah dan kompensasi terhadap kinerja guru adalah sebesar 16,2\% . Artinya 16,2\% peningkatan kinerja guru non
PNS SMP Swasta di sektor 1 Kabupaten Indramayu dapat dijelaskan oleh perbaikan pembinaan kepala sekolah dan kompensasi, sedangkan sisanya $83,8 \%$ dipengaruhi oleh faktor lain yang tidak diteliti.

\section{KESIMPULAN}

Berdasarkan dari hasil penelitian dan pembahasan mengenai pengaruh pembinaan kepala sekolah dan kompensasi terhadap kinerja guru non PNS SMP Swasta di Sektor 1 Kabupaten Indramayu, maka dapat disimpulkan hal-hal sebagi berikut :

1. Pembinaan kepala Sekolah SMP Swasta di Sektor 1 Kabupaten Indramayu memiliki pengaruh yang cukup signifikan terhadap kinerja guru, yaitu sebesar $13,5 \%$, sedangkan sisanya dipengaruhi oleh faktor lain.

2. Kompensasi pada SMP Swasta di Sektor 1 Kabupaten Indramayu memiliki pengaruh yang cukup signifikan terhadap kinerja guru yaitu sebesar $11,9 \%$, sedangkan sisanya dipengaruhi oleh faktor lain.

3. Secara bersama-sama pembinaan kepala sekolah dan kompensasi terhadap kinerja guru non PNS SMP Swasta di Sektor 1 Kabupaten Indramayu memiliki pengaruh sebesar 16,2\%, sedangkan sisanya yaitu sebesar $83,8 \%$ ditentukan oleh faktor lain. Dengan demikian, maka pengaruh pembinaan 
kepala sekolah dan kompensasi terhadap kinerja guru non PNS SMP Swasta di Sektor 1 Kabupaten Indramayu berada pada kategori yang cukup besar.

\section{DAFTAR PUSTAKA}

Ahmad, L.I. (2017). Konsep Penilaian Kinerja Guru dan Faktor yang Mempengaruhinya, Jurnal Idaarah, Vol. 1, No. 1, Juni 2017, Hal 133-142.

Dekawati, I. (2011), Manajemen Pengembangan Guru Profesional (Suatu Tinjauan Teoritik dan Empirik), Bandung: Rizqi Press.

Dewi R.S, dkk. (2018). Kemampuan Profesional Guru dan Motivasi Kerja Terhadap Kinerja Mengajar Guru Sekolah Dasar. Jurnal Administrasi Pendidikan, Vol. 24, No.1, April 2018, hal 150-158.

Dinas Pendidikan Kabupaten Indramayu. (2015). Nilai Uji Kompetensi Guru Smp Negeri Di Sektor I Kabupaten Indramayu Tahun 2015

Helmi, A. (2015). Kinerja Guru dalam Meningkatkan Prestasi Siswa pada SMP Negeri 2 Babahrot Aceh Barat Daya. Jurnal Administrasi Pendidikan Pascasarjana Universitas Syiah Kuala, Vol 3, No. 1, Februari 2015.

Ismail, M.I. (2010). Kinerja dan Motivasi Guru dalam Pembelajaran. Lentera Pendidikan, Vol 10, No 1, Juni 2010, Hal 44-63.

M. Shabir U. (2015). Kedudukan Guru Sebagai Pendidik: (Tugas dan Tanggung Jawab, Hak dan Kewajiban, dan Kompetensi Guru). Auladuna,
Vol. 2, No. 2, Desember 2015, Hal 221-232.

Napitupulu, E.L. (2012). Kompetensi guru memprihatinkan, https://edukasi.ko mpas.com/read/2012/07/25/1941337 9/kompetensi.guru.

Suherman, A \& Saondi, O. (2010). Etika Profesi Keguruan Bandung: PT. Refika Aditama.

Sugiyono. (2011), Metode Penelitian Pendidikan (Pendekatan kuantitatif, Kualitatif, dan $R \& D)$. Bandung: Alfabeta.

Wulantika, S. (2015). Kualitas Pendidikan Indonesia. Diakses: http:// www.kompasiana.com/www.savana of edelweis.com

Zubaidah, N. (2012). Hasil Uji Kompetensi Guru Memprihatinkan. Diakses:

https://nasional.sindonews.com/read/66287 3/15/hasil-uji-kompetensi-gurumemprihatinkan-1344004590 